\title{
THE FIRST RECORD OF MICROPROSTHEMA INORNATUM MANNING \& CHACE, 1990 (DECAPODA, SPONGICOLIDAE) FROM THE TROPICAL EASTERN ATLANTIC
}

\footnotetext{
SAMMY DE GRAVE ${ }^{1,4}$ ), PAULO P. G. PACHELLE ${ }^{2}$ ) and PETER WIRTZ ${ }^{3}$ )

1) Oxford University Museum of Natural History, Parks Road, OX1 3PW, Oxford, U.K.

${ }^{2}$ ) Museu de Zoologia da Universidade de São Paulo, Av. Nazaré, 481, Ipiranga, São Paulo, SP, Brazil

3 ) Centro de Ciências do Mar, Universidade do Algarve, P-8000-117, Faro, Portugal
}

The genus Microprosthema occurs in the Atlantic, Indian and Pacific oceans (Saito \& Anker, 2014). In the Atlantic Ocean, the genus has only been reported from several localities in the western Atlantic and from a single record in the central Atlantic (Ascension Island, see Manning \& Chace, 1990). Currently, six species of the genus are known to occur in the Atlantic (Goy \& Martin, 2013), with Microprosthema semilaeve (von Martens, 1872) being the most common and widespread, occurring from Bermuda through Florida, the Caribbean Sea and the Gulf of Mexico, southwards to northeastern Brazil (Goy \& Martin, 2013). Microprosthema manningi Goy \& Felder, 1988 appears also to be reasonably widespread, being recorded from Isla de Providencia (Colombia), Belize, Veracruz (Mexico), Florida and the British Virgin Islands (the latter record as Microprosthema jareckii Martin, 2002). Three species, Microprosthema looensis Goy \& Felder, 1988 from Looe Key (Florida, U.S.A.), Microprosthema granatense Criales, 1997 from Granate Bay (Colombia), and Microprosthema tortugasensis Goy \& Martin, 2013 from the Dry Tortugas (Florida, U.S.A.), are only known for their respective holotypes.

Microprosthema inornatum Manning \& Chace, 1990 was described on the basis of a single, male specimen, collected in 1980 off North Point, Ascension Island, central Atlantic (Manning \& Chace, 1990). Despite intensive collecting on the island in recent years (De Grave et al., 2014), the species has not been encountered again and is evidently locally rather rare. A second specimen of the species was mentioned without much detail by Goy \& Martin (2013), as from 63-100 m depth

${ }^{4}$ ) Corresponding author; e-mail: sammy.degrave@oum.ox.ac.uk 
in the north-western Gulf of Mexico. This specimen was collected on 22 June 2005, and is deposited in the University of Louisiana at Lafayette Zoological Collection (ULLZ 7423) (D. L. Felder, pers. comm.). However, the lack of morphological information on the Gulf of Mexico specimen, as well as the differential depth range, raises potential questions on the conspecifity of this specimen.

The species has been mentioned several times in phylogenetic literature on Decapoda, based on sequences first reported in Bracken et al. (2009). It is however clear that this is based on a misidentification, as neither the holotype nor the ULLZ specimen were tissue plucked for that study (D. L. Felder, pers. comm.). Although, at present the sequences cannot be unambiguously linked to a deposited voucher specimen, the most likely identity of these sequences is $M$. semilaeve.

Here we report on a single specimen of the species, captured by PW from São Vicente Island, Republic of Cabo Verde, extending the range of the species to the eastern Atlantic. The present record is also the first time any member of the genus has been reported in the eastern Atlantic. The specimen is deposited in the Zoological Collections of the Oxford University Museum of Natural History, Oxford (OUMNH.ZC); post-orbital carapace length (pocl) is used as the standard measurement of size, expressed in $\mathrm{mm}$.

Family SPONGICOLIDAE Schram, 1986

Genus Microprosthema Stimpson, 1860

Microprosthema inornatum Manning \& Chace, 1990

(figs. 1, 2)

Material examined.- One male (pocl $2.1 \mathrm{~mm}$ ), OUMNH.ZC.2015-02-037, Republic of Cabo Verde, São Vicente Island, $3 \mathrm{~km}$ north-east of Mindelo, $10 \mathrm{~m}$ depth, in fissure in rocks, leg. P. Wirtz, 26.viii.2015.

Description.- Rostrum reaching to end of penultimate segment of antennular peduncle; ascending distally; armed dorsally with 8 teeth (penultimate one doubled), ventrally with 2 teeth (fig. 1A, B). Carapace unadorned except for antennal tooth, 3 teeth on anterior margin (above the pterygostomial angle), 2 post-orbital teeth, a pseudo-hepatic tooth and 5 teeth immediately posterior to cervical groove (fig. 1A, B). Abdominal pleura 2-5 acute, $2^{\text {nd }}, 3^{\text {rd }}$ and $5^{\text {th }}$ with small tooth on anterior margin, $4^{\text {th }}$ with small tooth on anterior and posterior margins (fig. 1C). Abdominal sternites 1-5 each armed with mesial tooth (fig. 1D). Telson with pronounced mesial sulcus, flanked by series of 5 teeth, one pair of large, lateral teeth near midlength; distal margin convex, armed with 3 small teeth (fig. 1E). Antennular peduncle (fig. 1F, G) with few, small teeth ventrally. Scaphocerite (fig. 1H) with lateral margin bearing 6 teeth, in distal half of margin. Third maxilliped as illustrated (fig. 1J). Uropod (fig. 1K) with endopod furnished with 2 large, lateral 

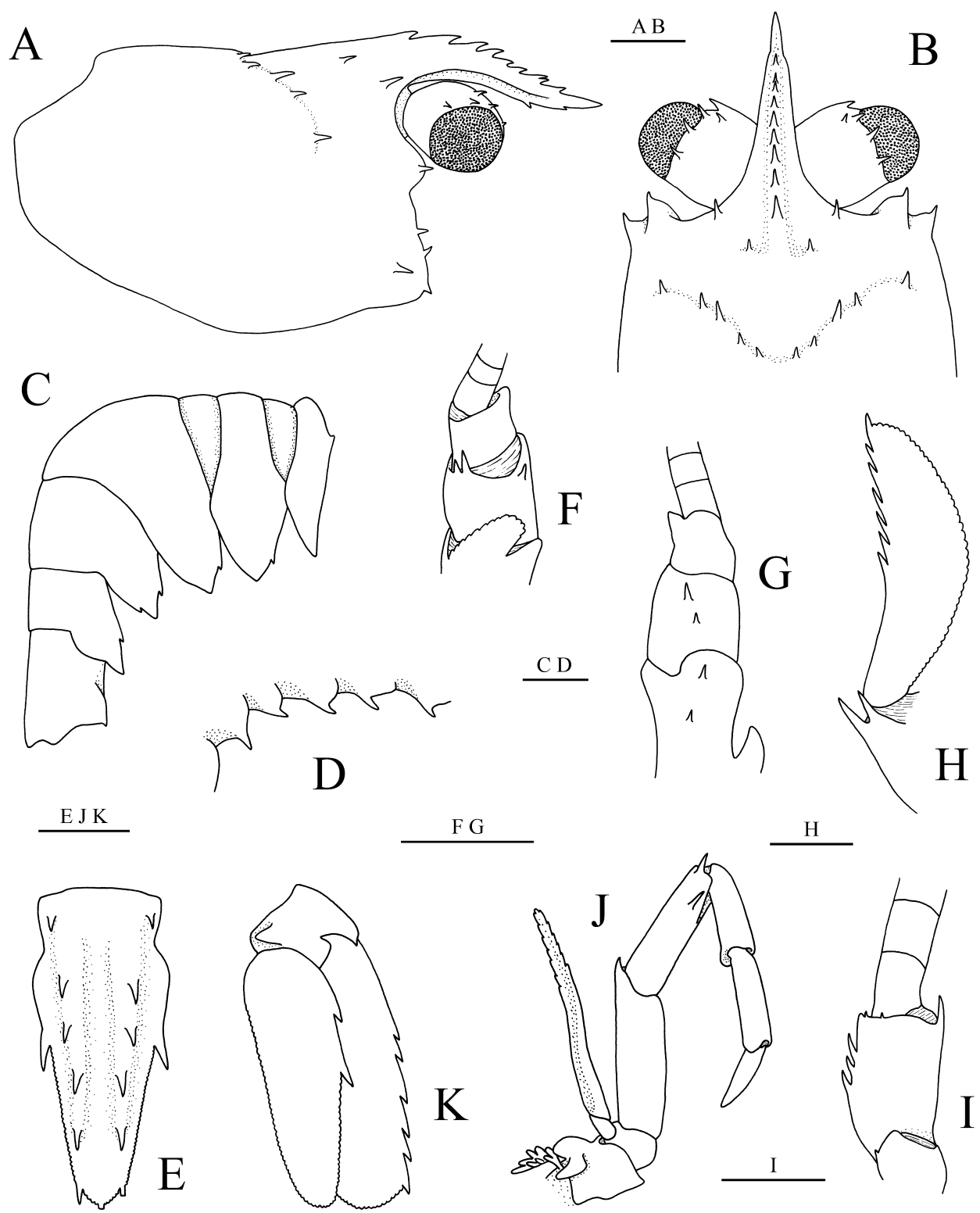

Fig. 1. Microprosthema inornatum Manning \& Chace, 1990, male from São Vicente Island, OUMNH.ZC.2015-02-037: A, carapace and eyes, lateral view; B, same, frontal region, dorsal view; $\mathrm{C}$, abdomen, lateral view; D, abdominal sternites 1-6, latero-ventral view; E, telson, dorsal view; F, left antennular peduncle, dorso-lateral view; G, same, ventral view; H, left scaphocerite and part of basicerite, dorsal view; I, left carpocerite, ventral view; J, right third maxilliped, lateral view; K, right uropod, dorsal view. Setae omitted. Scale bars indicate $0.5 \mathrm{~mm}$. 


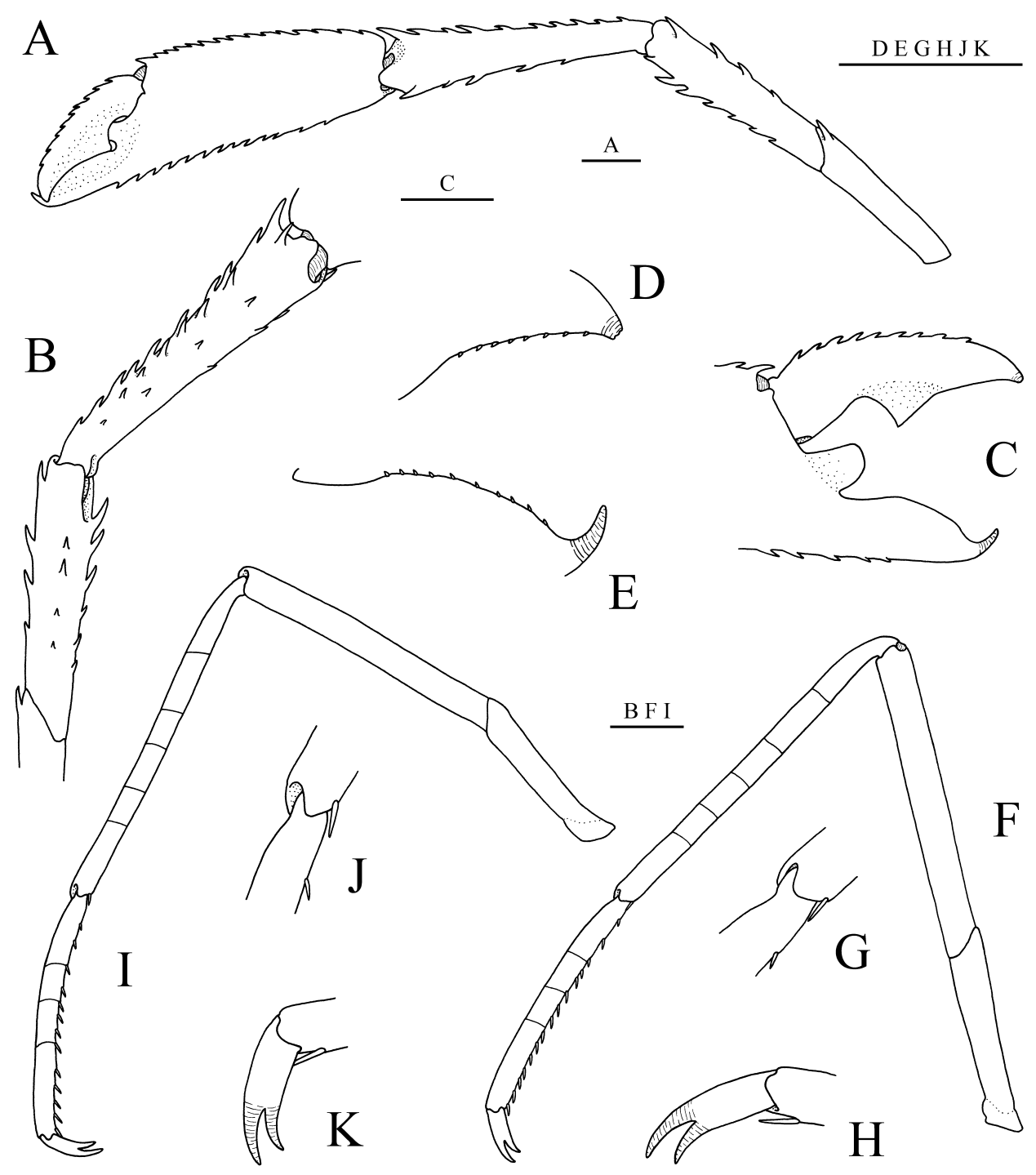

Fig. 2. Microprosthema inornatum Manning \& Chace, 1990, male from São Vicente Island, OUMNH.ZC.2015-02-037: A, right third pereiopod (cheliped), dorsal (mesial) view; B, same, distal ischium to proximal propodus, ventral (lateral) view; C, same, distal chela, ventral (lateral) view; D, same, detail of flexor margin of dactylus, lateral view; E, same, detail of flexor margin of propodus, lateral view; F, left fourth pereiopod, lateral view; G, same, detail of propodo-carpal joint, lateral view; $\mathrm{H}$, same, distal propodus and dactylus, lateral view; I, left fifth pereiopod, lateral view; J, same, detail of propodo-carpal joint, lateral view; K, same, distal propodus and dactylus, lateral view. Setae omitted. Scale bars indicate $0.5 \mathrm{~mm}$. 
teeth; exopods lateral margin with series of teeth in distal half. Third pereiopods (chelipeds) slightly unequal and dissimilar. Right member of pair (fig. 2A-E) with movable finger armed with 9 teeth on extensor margin; propodus with 15 small teeth on extensor margin (dorsal crista) and 13 teeth on flexor margin; carpus with 10 teeth along extensor margin, 5 along flexor margin as well as scattered on ventral surface; merus with 4 teeth on extensor margin, 7 on flexor margin and 4 along ventral surface; ischium with subdistal tooth on extensor margin. Fingers (fig. 2D, E) with series of small teeth on distal half of cutting edges. Fourth pereiopod (fig. 2F-H) with carpus divided into 6 segments, carpo-propodal junction with distinct spinule on flexor margin; propodus divided into 4 segments and armed with 15 spinules along flexor margin. Fifth pereiopod (fig. 2I-K) similar to fourth.

Remarks. - Although the specimen exhibits some differences from the holotype, especially in armature of the carapace and chelipeds, these are herein interpreted as individual variation and there seems to be little doubt on the identification of the specimen.

Colour pattern.- The specimen was generally milky-white transparent, with no noticeable banding or coloured areas (based on an underwater photo by PW).

Distribution.- The species is currently known from Ascension Island (Manning \& Chace, 1990), the north-western Gulf of Mexico (Goy \& Martin, 2013) and São Vicente Island (Republic of Cabo Verde, present record).

Ecological notes.- As with most species in the genus, the ecology of M. inornatum remains poorly known. The holotype was collected from a fish poison station at $18 \mathrm{~m}$ depth, whilst the present specimen was collected by hand from a crack in rocky substrate at $10 \mathrm{~m}$ depth. Potentially, the species also occurs in much deeper water, as the Gulf of Mexico specimen assigned to this species by Goy \& Martin (2013) was trawled up from 63-100 m depth.

\section{ACKNOWLEDGEMENTS}

The second author is grateful to Coordenação de Aperfeiçoamento de Pessoal de Nivel Superior (CAPES) of the Ministry of Education of the Brazilian Government, for providing financial support in the form of an MSc scholarship. D.L. Felder, H. Bracken-Grissom and K.A. Crandall provided information on the other recorded specimens.

\section{REFERENCES}

Bracken, H. D., A. Toon, D. L. Felder, J. W. Martin, M. Finley, J. Rasmussen, F. Palero \& K. A. Crandall, 2009. The decapod tree of life: compiling the data and moving toward a consensus of decapod evolution. Arthropod Systematics \& Phylogeny, 67: 99-116. 
CRIALES, M. M., 1997. Microprosthema granatense, new species, from the southern Caribbean, with a key to shrimps of the genus Microprosthema from the western Atlantic and a new record of Odontozona libertae (Decapoda: Stenopodidea). Journal of Crustacean Biology, 17: 538545.

De Grave, S., A. Anker, P. C. Dworschak, P. F. Clark \& P. Wirtz, 2014. An updated checklist of the marine Decapoda of Ascension Island, central Atlantic Ocean. Journal of the Marine Biological Association of the United Kingdom. Available online at http://dx.doi.org/ $10.1017 /$ S0025325414001295.

Goy, J. W. \& D. L. Felder, 1988. Two new species of Microprosthema from the western Atlantic (Crustacea: Decapoda: Stenopodidea). Journal of Natural History, 22: 1277-1292.

Goy, J. W. \& J. W. MARTin, 2013. Redescription of Microprosthema semilaeve (von Martens, 1872) (Decapoda: Stenopodidae: Spongicolidae) and description of a new species of Microprosthema from Dry Tortugas, Florida. Zootaxa, 3630: 467-488.

MANNing, R. B. \& F. A. CHACE JR., 1990. Decapod and stomatopod Crustacea from Ascension Island, south Atlantic Ocean. Smithsonian Contributions to Zoology, 503: 1-91.

MARTIN, J. W., 2002. Microprosthema jareckii, a new species of stenopodidean shrimp (Crustacea: Decapoda: Stenopodidea: Spongicolidae) from Guana Island, British Virgin Islands. Proceedings of the Biological Society of Washington, 115: 108-117.

SAito, T. \& A. AnKer, 2014. Two new species and new records of Microprosthema Stimpson, 1860 (Crustacea: Decapoda: Stenopodidea: Spongicolidae) from the Indo-West Pacific. Zootaxa, 3857: 183-206.

Schram, F. R., 1986. Crustacea. (Oxford University Press, New York, NY).

STIMPSON, W., 1860. Prodromus descriptionis animalium evertebratorum, quae in Expeditione as Oceanum Pacificum Septentrionalem, a Republic Federata missa, Cadwaladore Ringgold et Johanne Rodgers Ducibus, observavit et descripsit. Pars VIII, Crustacea Macrura. Proceedings of the Academy of Natural Sciences of Philadelphia, 1860: 22-47.

von Martens, E., 1872. Ueber Cubanische Crustaceen. Archiv für Naturgeschichte, 38: 77-147.

First received 7 November 2015.

Final version accepted 17 November 2015. 